Vol. 6, No. 1 Januari - Juni 2017

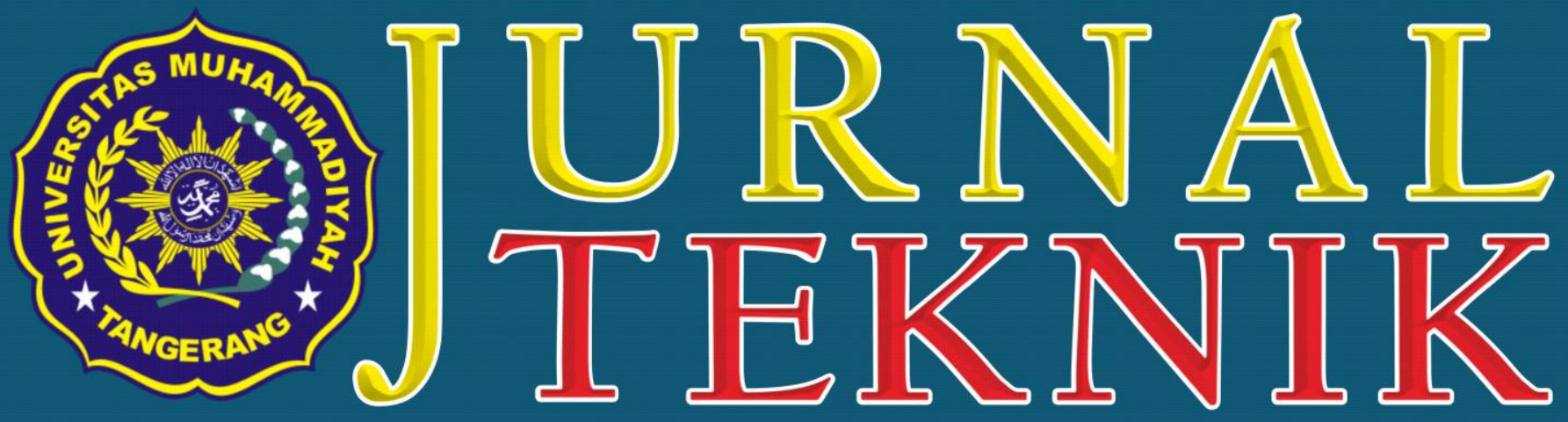

Alamat Redaksi: Jl. Perintis Kemerdekaan I No. 33, Cikokol Tangerang - TIp. (021) 51374916

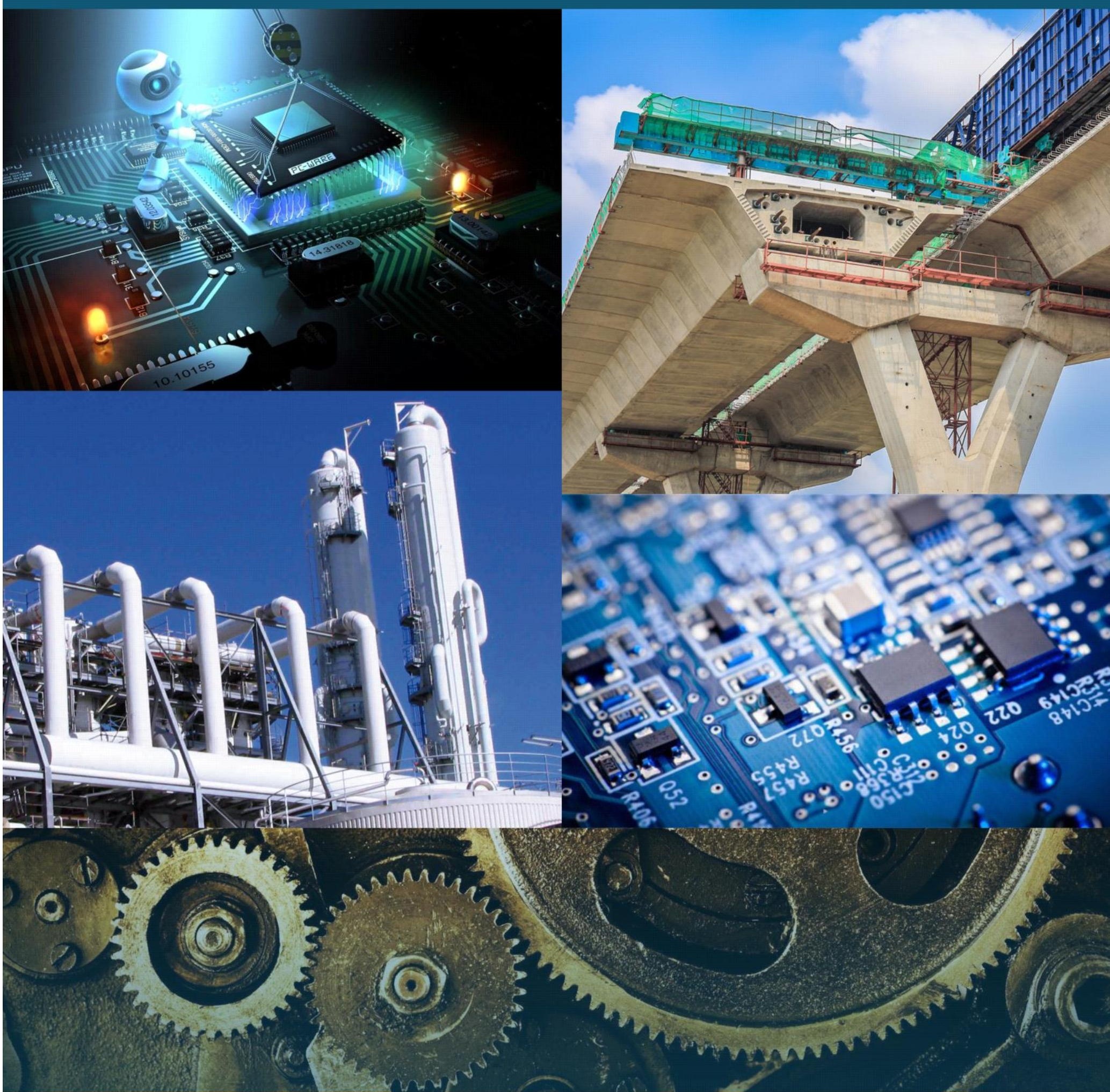




\section{J U R N A L TEKN I K}

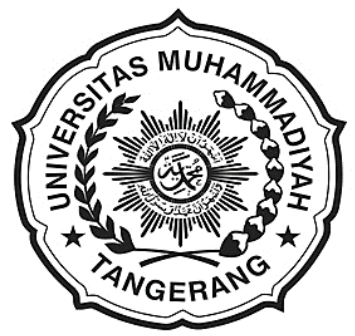

\section{UNIVERSITAS MUHAMMADIYAH TANGERANG}

Pelindung:

Dr. H. Achmad Badawi, S.Pd., SE., MM. (Rektor Universitas Muhammadiyah Tangerang)

Penanggung Jawab:

Ir. Saiful Haq, ST., M.Si.

(Dekan Fakultas Teknik)

Pembina Redaksi:

Rohmat Taufik, ST., M.Kom.

Drs. H. Syamsul Bahri, MSi.

Pimpinan Redaksi:

Ir. Sumardi Sadi, S.Pd., ST., MT.

Redaktur Pelaksana:

Yafid Efendi, ST, MT.

Editor Jurnal Teknik UMT:

Ir. Sumardi Sadi, S.Pd., ST., MT.

Dewan Redaksi:

Ir. Ali Rosyidin, ST., MM., MT.

Tri Widodo, ST.,MT.

Tina Herawati, ST., MT

Almufid, ST., MT.

Siti Abadiah, ST., MT.

M. Jonni, SKom., MKom.

Syepry Maulana Husain, S.Kom., M.Kom.

Ir. H. Bayu Purnomo, ST., MT

Kasubag:

Ferry Hermawan, MM.

Keuangan:

Elya Kumalasari, S.Ikom.

Setting \& Lay Out:

Muhlis, S.E

Saiful Alam, SE.

Mitra Bestari:

Prof. Dr. Aris Gumilar

Ir. Doddy Hermiyono, DEA

Dr. Ir. Budiyanto, MT.

Dr. Alimuddin, ST., MM., MT

J U R N A L T E K N I K

Diterbitkan Oleh:

Fakultas Teknik Universitas Muhammadiyah Tangerang

Alamat Redaksi:

Jl. Perintis Kemerdekaan I No. 33, Cikokol Tangerang Tlp. (021) 51374916

\begin{tabular}{|c|c|c|c|c|c|}
\hline \multirow{2}{*}{$\begin{array}{c}\text { Jurnal } \\
\text { Teknik }\end{array}$} & 6 & 1 & $1-97$ & $\begin{array}{c}\text { Jan'-Juni } \\
2017\end{array}$ & ISSN \\
\cline { 2 - 6 } & $2302-8734$ \\
\hline
\end{tabular}

\section{DAFTAR ISI}

1. PROSES PEMBUATAN ALAT PEMBUKA KALENG CAT DENGAN METODE CETAK PASIR (SAND CASTING) - 1-11 Ali Rosyidin

2. ANALISA DAN PERANCANGAN SISTEM KENDALI PLC XBC MINI BAS - 12-18 Alim Hardiansyah \& Bambang Suardi Waluyo

3. PENGATUR KESTABILAN SUHU PADA EGG INCUBATOR BERBASIS ARDUINO - 19-22

Abel Putra Hidayah \& Sumardi Sadi

4. METODE PEMBUATAN PONDASI BORE PILE DENGAN KINGPOST DAN METODE PONDASI DINDING PENAHAN TANAH DIAFRAGMA WALL - 23-29

Almufid

5. RANCANG BANGUN SIMULASI PENGENDALI LAMPU LALU LINTAS PADA PERSIMPANGAN DENGAN LIMA JALUR - 30-39

Rahma Farah Ningrum, Puji Catur Siswipraptini, \& Rosida N. Aziza

6. PERANCANGAN PROGRAM APLIKASI PENGENALAN WAJAH DENGAN MENERAPKAN METODE PRINCIPAL COMPONENT ANALYSIS DAN JARINGAN SYARAF TIRUAN - 40-49

M. Lutfi Aksani

7. KAJIAN PENERAPAN SI / TI DALAM MENINGKATKAN KUALITAS PEMBELAJARAN PADA TRAINING CENTER DENGAN MENGGUNAKAN METODOLOGI DeLone And McLean: STUDI KASUS PADA BINUS CENTER JAKARTA - 50-62 Nyoman Ayu Gita Gayatri \& GG Faniru Pakuning Desak

8. RANCANG BANGUN APLIKASI PEMBELAJARAN MATEMATIKA SD KELAS 6 BERBASIS ANDROID PADA SDN CIMONE 1 TANGERANG - 63-69

Winda Anggraeni \& Sri Mulyati

9. RANCANG BANGUN MESIN PERAJANG SINGKONG INDUSTRI RUMAHAN BERDAYA RENDAH - 70-76

Yafid Effendi \& Agus Danang Setiawan

10. RANCANG BANGUN TONGKAT ULTRASONIK UNTUK PENYANDANG TUNA NETRA BERBASIS ARDUINO UNO - 77-82

Bayu Purnomo \& Basuki Isnanto

11. ENTERPRISE RISK MANAGEMENT PADA CLOUD COMPUTING - 83-87

Samudera Dipa Legawa

12. ANALISIS NETWORK PLANNING DENGAN CRITICAL PATH METHOD (CPM) PADA PROYEK UNINTERATUBLE POWER SUPPLY (UPS) 80KVA PADA PT. HARMONI MITRA SUKSES (STUDI KASUS: RSAB HARAPAN KITA, JAKARTA) - 88-97

Hermanto, Novy Fauziah, \& Elfitria Wiratmani 


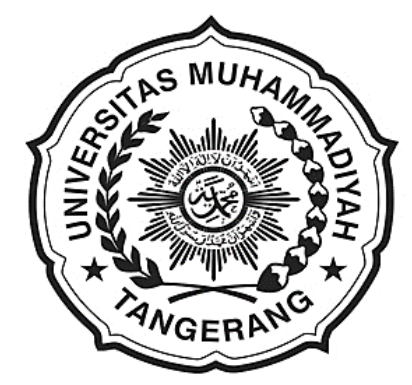

\section{Sambutan Dekan \\ Fakultas Teknik \\ Universitas Muhammadiyah Tangerang}

Puji Syukur kehadirat Allah Swt. karena berkat karunia dan ijin-Nyalah Tim penyusun Jurnal Teknik Fakultas Teknik Universitas Muhammadiyah Tangerang dapat menyelesaikan tugasnya tepat sesuai dengan waktu ditetapkan.

Saya menyambut baik diterbitkannya Jurnal Teknik Vol. 6 No. 1, Januari-Juni 2017, terbitnya jurnal ini, merupakan respon atas terbitnya Peraturan Menteri Pendidikan Nasional No. 17 Tahun 2010 tentang Pencegahan dan Penanggulangan Plagiat di Perguruan Tinggi; Surat Dirjen Dikti Nomor 2050/E/T/2011 tentang kebijakan unggah karya ilmiah dan jurnal; Surat Edaran Dirjen Dikti Nomor 152/E/T/2012 tertanggal 27 Januari 2012 perihal publikasi karya ilmiah yang antara lain menyebutkan untuk lulusan program sarjana terhitung mulai kelulusan setelah 2012 harus menghasilkan makalah yang terbit pada jurnal ilmiah.

Terbitnya Jurnal ini juga diharapkan dapat mendukung komitmen dalam menunjang peningkatan kemampuan para dosen dan mahasiswa dalam menyusun karya ilmiah yang dilandasi oleh kejujuran dan etika akademik. Perhatian sangat tinggi yang telah diberikan rektor Universitas Muhammadiyah Tangerang khususnya mengenai plagiarism dan cara menghindarinya, diharapkan mampu memacu semangat dan motivasi para pengelola jurnal, para dosen dan mahasiswa dalam menyusun karya ilmiah yang semakin berkualitas.

Saya mengucapkan banyak terimakasih kepada para penulis, para pembahas yang memungkinkan jurnal ini dapat diterbitkan, dengan harapan dapat dimanfaatkan seoptimal mungkin dalam peningkatan kualitas karya ilmiah.

Dekan Fakultas Teknik

Universitas Muhammadiyah Tangerang,

\section{Ir. Saiful Haq, M.Si.}




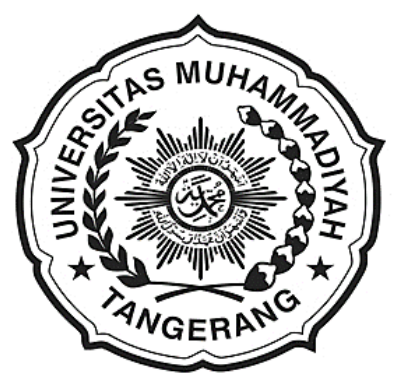

\section{Pengantar Redaksi}

Jurnal Teknik

Universitas Muhammadiyah Tangerang

Puji dan Syukur Alhamdulillah kami panjatkan kehadapan Allah Swt. atas karunia dan lindungan-Nya sehingga Jurnal Teknik Vol. 6 No. 1 edisi Januari-Juni 2017 dapat diterbitkan.

Menghasilkan karya ilmiah merupakan sebuah tuntutan perguruan tinggi di seluruh dunia. Tri Dharma Perguruan Tinggi yaitu darma pendidikan, darma penelitian, dan darma pengabdian kepada masyarakat mendorong lahirnya dinamika intelektual diantaranya menghasilkan karyakarya ilmiah. Penerbitan Jurnal Teknik ini dimaksudkan sebagai media dokumentasi dan informasi ilmiah yang sekiranya dapat membantu para dosen, staf dan mahasiswa dalam menginformasikan atau mempublikasikan hasil penelitian, opini, tulisan dan kajian ilmiah lainnya kepada berbagai komunitas ilmiah.

Buku Jurnal yang sedang Anda pegang ini menerbitkan 12 artikel yang mencakup bidang teknik sebagaimana yang tertulis dalam daftar isi dan terdokumentasi nama dan judul-judul artikel dengan jumlah halaman 1-97 halaman.

Jurnal Teknik ini tentu masih banyak kekurangan dan masih jauh dari harapan, namun demikian tim redaksi berusaha untuk ke depannya menjadi lebih baik dengan dukungan kontribusi dari semua pihak. Harapan Jurnal Teknik akan berkembang menjadi media komunikasi intelektual yang berkualitas, aktual dan faktual sesuai dengan dinamika di lingkungan Universitas Muhammadiyah Tangerang.

Tak lupa pada kesempatan ini kami mengundang pembaca untuk mengirimkan naskah ringkasan penelitiannya ke redaksi kami. Kami sangat berterimakasih kepada semua pihak yang telah membantu penerbitan Jurnal Teknik ini semoga buku yang sedang Anda baca ini dapat bermanfaat.

Pimpinan Redaksi Jurnal Teknik

Universitas Muhammadiyah Tangerang,

Ir. Sumardi Sadi, S.Pd., ST., MT. 


\title{
PERANCANGAN PROGRAM APLIKASI PENGENALAN WAJAH DENGAN MENERAPKAN METODE PRINCIPAL COMPONENT ANALYSIS DAN JARINGAN SYARAF TIRUAN
}

\author{
M. Lutfi Aksani \\ Program Studi Teknik Informatika \\ Universitas Muhammadiyah Tangerang \\ Jl. Perintis Kemerdekaan I/33, Cikokol - Tangerang-Banten \\ E-mail:113fie@gmail.com
}

\begin{abstract}
ABSTRAK
Perancangan program aplikasi pengenalan wajah dengan menerapkan metode principal component analysis. Informasi mengenai seseorang saat ini sangat penting dan sulit didapat jika datanya sangat banyak. Salah satu teknik untuk mendapatkan informasi mengenai seseorang adalah dari foto wajah orang tersebut, di mana dari foto tersebut akan didapat identitas orang yang bersangkutan, yang kemudian akan didapat informasi orang tersebut pula. Banyak orang telah mencoba dan berhasil membangun program aplikasi pengenalan wajah dengan berbagai macam metode yang masing-masing memiliki kelebihan dan kekurangannya. Ada metode yang cepat dalam mengenali citra wajah, tetapi mengorbankan keakuratan pengenalan, begitu pula sebaliknya. Tujuan penelitian ini adalah untuk merancang dan membangun sebuah program aplikasi pengenalan wajah dengan memanfaatkan metode Principal Component Analysis. Dalam penelitian ini, penulis membuat program pengenalan wajah mulai dari objek berupa citra wajah, deteksi sisi, hingga mendapatkan karakteristik citra tersebut. Penulis membuat program lalu mengujinya. Setelah dilakukan pengujian, diperoleh hasil analisa bahwa program dapat mengenal sebagian besar citra wajah yang diuji. Beberapa kesalahan pengenalan terjadi karena program kesulitan dalam membedakan bentuk wajah yang banyak kesamaannya.
\end{abstract}

Kata Kunci: Pengenalan Wajah, Principal Component Analys, Jaringan Syaraf Tiruan, Analisis Komponen Utama, Citra.

\section{PENDAHULUAN}

Wajah atau muka adalah bagian depan dari kepala, pada manusia meliputi wilayah dari dahi hingga dagu, termasuk rambut, dahi, alis, mata, hidung, pipi, mulut, bibir, gigi, kulit, dan dagu. Wajah terutama digunakan untuk ekspresi wajah, penampilan, serta identitas. Tidak ada satu wajah pun yang serupa mutlak, bahkan pada manusia kembar identik sekalipun. Oleh sebab itu dengan melihat wajah, manusia dapat mengenali atau mengidentifikasi seseorang dengan mudah.[1]

Secara harfiah, citra (image) adalah gambar pada bidang dwimatra (dua dimensi). Ditinjau dari sudut pandang matematis, citra merupakan fungsi menerus (continue) dari intensitas cahaya pada bidang dua dimensi. Sumber cahaya menerangi objek, objek memantulkan kembali sebagian dari berkas cahaya tersebut. Pantuan cahaya ini ditangkap oleh alat-alat optik, misalnya mata pada manusia, kamera, pemindai (scanner), dan sebagainya, sehingga bayangan objek yang disebut citra tersebut terekam.

Pengenalan wajah merupakan suatu pengenalan pola (pattern recognition) yang khusus untuk kasus wajah. Beberapa pendekatan untuk pengenalan objek dan grafika komputer didasarkan secara langsung pada citra-citra tanpa penggunaan model tiga dimensi. Yang termasuk dalam kelompok ini antara lain: Analisis Komponen Utama (Principal Component Analysis-PCA), dan 
jaringan syaraf tiruan. PCA adalah suatu metode ekstraksi ciri atau kompresi data yang mampu mengidentifikasi ciri tertentu yang merupakan karakteristik suatu citra (dalam hal ini adalah wajah).

Dalam tugas akhir ini dicoba penggabungan dua metode untuk mengenali wajah manusia dalam beberapa ekspresi dan posisi, yaitu PCA dan jaringan syaraf tiruan perambatan-balik. Sehingga diperoleh kesimpulan tentang penggabungan dua metode tersebut sebagai sebuah metode pengenalan wajah.

Tujuan yang ingin dicapai dalam tugas akhir ini adalah membuat program bantu pengenalan wajah manusia menggunakan anal isis komponen utama (PCA) dan untuk membuat software yang dapat mengidentifikasi wajah seseorang berdasarkan eigen face yang dimiliki suatu image, dan dibandingkan dengan image yang menjadi training pada database.

Terdapat beberapa algoritma tentang pengenalan wajah, salah satunya algoritma yang berdasarkan appearance based yang banyak digunakan dalam sistem pengenalan wajah, dan juga dikenal dengan metode eigenface. Pada metode ini setiap citra wajah dianggap sebagai suatu vector tunggal dengan cara menderetkan kolom-kolom pada citra wajah menjadi satu vektor yang panjang. Untuk mendapatkan eigenface yang akan berfungsi sebagai fitur, digunakan analisa komponen utama yaitu PCA (Principal Component Analysis). PCA digunakan untuk mendapatkan vektor-vektor atau disebut juga sebagai principal component yang dapat memberikan informasi tentang varian maksimum database wajah. Pemakaian algoritma PCA ini proses pengenalannya menggunakan metode pengukuran jarak, diantaranya: Pendekatan PCA, Perhitungan PCA, Klasifikasi Identitas.

Dalam pengenalan wajah terdapat dua masalah penting diantaranya pemodelan citra wajah (face representation) yang terdiri dari feature based dan holistic based, dan proses pencocokan (matching). Kedua masalah ini dalam pengenalan wajah juga dipengaruhi oleh kendala PIE (Pose, Illumination, Expression) yang menyebabkan algoritma pengenalan wajah tidak bekerja secara optimal. Spesifikasi system pengenalan wajah[9] diantaranya Identifikasi, Recog- nition, dan Categorization. Berdasarkan kesepakatan pada masing-masing algoritma yang ada, wajah akan diproses untuk mengurangi variasi citra seperti iluminasi dan pengenalan nama citra tersebut. Proses normalisasi dilakukan untuk menambah atau memperbaiki akurasi dari sebuah citra. Pengaruh pencahayaan dibagi menjadi tiga yaitu model pantulan, colour constancy, dan histogram equalization.

Principal Component Analysis (PCA) adalah teknik reduksi dimensi yang umum digunakan pada aplikasi pemrosesan citra. PCA adalah suatu ekstraksi fitur dan teknik reduksi dimensi yang optimal jika dipandang dari sudut pandang teori informasi. Ide dasarnya adalah menentukan komponen utama dari serangkaian citra yang mengumpul membentuk suatu arah menurut varian maksimumnya. Maka dimensidimensi yang berkontribusi tersebutlah yang dipertahankan dan sisanya disingkirkan untuk tahap pemrosesan berikutnya.[2]

Penggunaan algoritma PCA untuk mereduksi dimensi yang tinggi ke dimensi yang lebih rendah sehingga lebih mudah dalam penghitungannya. Pengenalan wajah pada intinya adalah pencocokan dua wajah dimana wajah yang satu merupakan wajah yang telah dilatih dan ditempatkan didalam database kemudian dibandingkan dengan citra wajah tes atau citra wajah baru. Pencocokan tersebut salah satunya dengan menggunakan metode pengukuran jarak. Pada dasarnya pengukuran jarak digunakan untuk menghitung perbedaan antara dua vector citra dalam eigenspace. Setelah citra wajah diproyeksikan ke dalam space wajah, tugas selanjutnya adalah menentukan citra wajah yang mana yang paling mirip dengan citra dalam database. Ada banyak cara dalam mengukur tingkat kesamaan dan jarak. Diantaranya jarak Euclidean, Manhattan, Mahalanobis, Correlation, Angle-based, Squarred Euclidean. Dan pada akhirnya akan dibandingkan jarak manakah yang memiliki tingkat kecocokan paling tinggi.

\section{METODOLOGI / LANDASAN \\ 2.1 Pendekatan PCA}

Di tahun 1933, Hotelling mengajukan sebuah teknik untuk mengurangi dimensi sebuah ruang yang direpresentasikan oleh 
variabel statistik $\mathrm{x} 1, \mathrm{x} 2, \ldots, \ldots \mathrm{xn}$, dimana variable tersebut biasanya saling berkorelasi satu dengan yang lain. Selanjutnya Hotelling menyebut metode tersebut sebagai Principal Component Analysis (PCA) atau kadang juga Transformasi Hotelling atau disebut juga Transformasi Karhunen-Loeve [Prasetyo dan Rahmatun, 2008].

Transformasi Karhunen-Loeve banyak digunakan untuk memproyeksikan atau mengubah suatu kumpulan data berukuran besar menjadi bentuk representasi data lain dengan ukuran yang lebih kecil. Transformasi Karhunen-Loeve terhadap sebuah ruang data yang besar akan menghasilkan sejumlah vektor basis ortonormal ke dalam bentuk kumpulan vektor eigen dari suatu matriks kovarian tertentu, yang dapat secara optimal merepresentasikan distribusi data.

Pengenalan wajah dengan pendekatan Eigenface dapat digolongkan dalam suatu metoda appearance-based, ini dikarenakan pengenalan wajah eigenface menggunakan informasi mentah dari pixel citra yang kemudian direpresentasikan dalam metode tertentu (misalnya Principal Component Analysis (PCA), transformasi wavelet, dll) yang selanjutnya digunakan untuk pelatihan dan klasifikasi indentitas citra. Ide dari metode ini adalah memproyeksikan sebuah wajah yang merupakan sebuah citra dapat dilihat sebagai sebuah vektor.

Metode PCA yang juga dikenal dengan nama Karhunen-Loeve transformation (KLT), sudah dikenal sejak 30 tahun lalu dalam dunia pengenalan pola. PCA memberikan transformasi ortogonal yang disebut dengan 'eigenimage' yang mana sebuah image direpresentasikan kedalam bentuk proyeksi linier searah dengan eigenimage yang bersesuaian dengan nilai eigen terbesar dari matrix covariance. Secara praktis matrix covariance ini dibangun dari sekumpulan image training yang diambil dari berbagai obyek/kelas.

Pengenalan citra wajah dengan metode Eigenface dilakukan berdasarkan pada pengurangan dimensi ruang wajah dengan menggunakan Principal Component Analysis (PCA) untuk memperoleh ciri wajah. Tujuan utama penggunaan metode PCA pada pengenalan wajah dengan menggunakan eigenfaces adalah membentuk (ruang wajah) dengan cara mencari vektor eigen yang berkoresponden dengan nilai eigen terbesar dari citra wajah. Vektor eigen ini menyatakan posisi dari Principal Component dalam suatu ruang dimensi n. Sebelum mengaplikasikan metode PCA dalam hal ini mereduksi dimensi dari vektor fitur yang ada maka nilai eigen dari citra wajah yang ada perlu diurutkan terlebih dahulu sehingga nantinya didapat nilai eigen yang tereduksi yang diinginkan. [3]

\subsection{Perhitungan PCA}

Konstruksi eigenface adalah pembuatan suatu set eigenface dari set gambar training dengan menggunakan perhitungan Principal Component Analysis (PCA). Perhitungan PCA dapat dilakukan dengan langkahlangkah sebagai berikut: [9]

1. Mengambil satu set gambar training dan kemudian mentransformasikan setiap gambar tersebut menjadi vektor kolom, sehingga akan didapat satu matriks yang tiap kolomnya mewakili gambar yang berbeda, face space . Misalkan terdapat:

$\boldsymbol{m}=$ jumlah sample wajah

$\boldsymbol{n}=$ ukuran tinggi $=$ ukuran lebar citra wajah

$\begin{array}{lllll}r_{1} & r_{2} & r_{3} & \ldots & r_{m} \\ \mathrm{X}_{11} & \mathrm{X}_{12} & \mathrm{X}_{13} & \ldots & \mathrm{X}_{1 \mathrm{~m}} \\ \mathrm{X}_{21} & \mathrm{X}_{22} & \mathrm{X}_{23} & \ldots & \mathrm{X}_{2 \mathrm{~m}} \\ \mathrm{X}_{31} & \mathrm{X}_{32} & \mathrm{X}_{33} & \ldots & \mathrm{X}_{3 \mathrm{~m}} \\ \ldots & \ldots & \ldots & \ldots & \ldots \\ \mathrm{X}_{\mathrm{nnn} 1} & \mathrm{X}_{\mathrm{nXn} 2} & \mathrm{X}_{\mathrm{nxn} 3} & \ldots & \mathrm{X}_{\mathrm{nxn} \mathrm{m}}\end{array}$

2. Membentuk average face, yaitu nilai rata-rata dari seluruh gambar wajah pada training set, dan mengurangi seluruh gambar pada training set terhadap average face untuk mencari nilai deviasinya ;

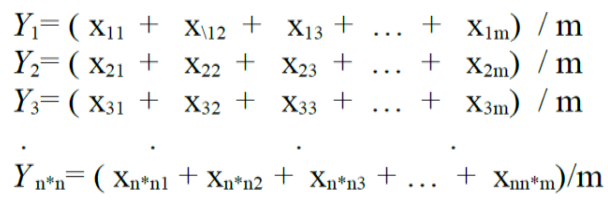

$$
\begin{aligned}
& F_{1}=r_{1}-Y_{1} \\
& F_{2}=r_{2}-Y_{2} \\
& F_{3}=r_{3}-Y_{3} \\
& \dot{F}_{\mathrm{n}^{*} \mathrm{n}}=r_{\mathrm{n}^{*} \mathrm{n}}-Y_{\mathrm{n}^{*} \mathrm{n}}
\end{aligned}
$$


3. Menghitung matriks kovarian, yaitu dengan melakukan operasi perkalian transpose dari training set.

4. Menghitung nilai eigen dan vektor eigen dari matriks kovarian.

5. Mengurutkan vektor eigen berdasarkan dengan besarya nilai eigen masingmasing vektor.

6. Menghitung matriks proyeksi PCA (Wpca) yaitu dengan mereduksi banyaknya vektor eigen menjadi $M^{\prime}$ vektor eigen (eigenfaces) dengan nilai $\mathrm{M}^{\prime}<\mathrm{M}<<\mathrm{N} 2$.

7. Menghitung bobot eigenface pada citra training yaitu dengan cara mengalikan matrik vektor eigen transpose dengan matrik beda yang hasilnya merupakan reprentasi bobot dari variasi wajah.

8. Hitung nilai tresholdnya/toleransi toleransi.[8]

\subsection{Klasifikasi Identitas}

Klasifikasi identitas yang dligunakan adalah dengan membandingkan bobot dari masingmasing eigenface pada gambar wajah pada training set dan gambar wajah masukan dengan menghitung jarak Eucidiannya. Langkah-langkah klasifikasi identitas adalah sebagai berikut:

1. Konversi citra wajah yang diuji dengan ukuran ke dalam bentuk vektor kolom.

2. Normalisasi citra wajah masukan terhadap citra training dengan cara mencari nilai matriks beda dengan mengurangkan dengan nilai rata-rata training set.

3. Menghitung bobot eigenface pada citra masukan dengan cara mengalikan matrik vektor eigen transpose dengan matrik yang hasilnya matriks.

4. Menghitung jarak perbedaan antara citra input dengan citra wajah yang di database (citra training) dengan menggunakan Euclidian minimum

Mencari dan membandingkan jarak minimum dengan satu nilai batas ( ). Sebuah citra dikatakan wajah jika jarak minimumnya lebih kecil dari nilai batas yang diterapkan / diberikan. Semakin kecil jarak minimum yang diperoleh semakin besar kesamaan (similarity) gambar masukan dengan pasangan gambar pada training set. Nilai batas toleransi bisa diperoleh dari hasil percobaan-percobaan hingga ditemukan hasil yang memuaskan atau bisa gunakan persamaan no. 8 pada perhitungan PCA.

\subsection{Analisis Komponen Utama (Principal Components Analysis-PCA)}
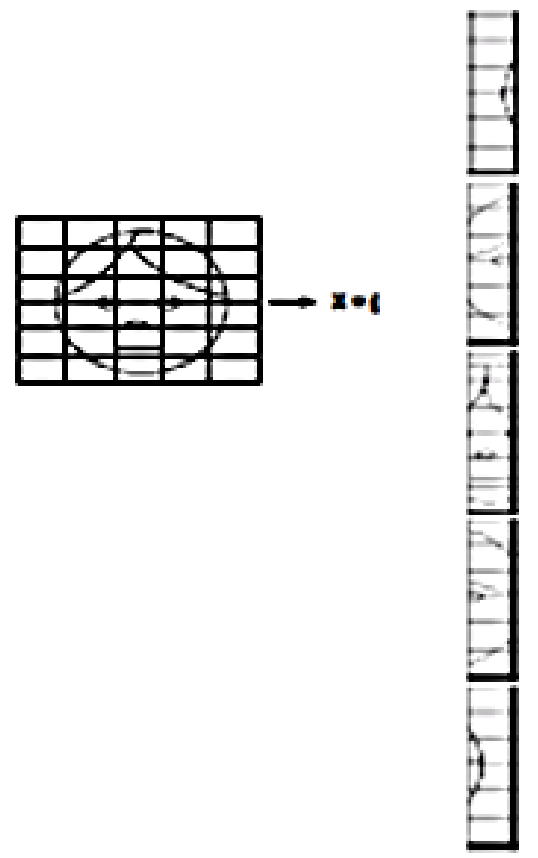

Gambar 2. Formasi Vektor Wajah dari Gambar Wajah

Sebuah wajah, yang merupakan sebuah gambar, dapat dilihat sebagai sebuah vektor. Jika panjang dan lebar dari gambar tersebut adalah $w$ dan $h$ piksel maka jumlah komponen dari vektor ini adalah $w * h$. Setiap piksel dikodekan oleh satu komponen vektor.

Algoritma PCA adalah sebagai berikut:

1. Sebelum PCA dapat dilakukan, dilakukan lexicographical ordering untuk setiap wajah yang akan dilatihkan dimana kolom yang satu diletakkan disamping kolom yang lain sehingga membentuk vektor wajah yang merupakan vektor kolom. Vektor vektor wajah tersebut disusun sedemikian rupa sehingga membentuk suatu matriks $\mathbf{X}$ dengan orde $n \times m$, dimana $n$ adalah banyak nya jumlah piksel $\left(w^{*} h\right)$ dan $m$ adalah banyak nya gambar wajah. Matriks inilah yang akan digunakan sebagai masukan bagi PCA.

2. Hitung rata-rata (mean) setiap baris dari matriks besar tersebut, lalu kurangi 
semua nilai di setiap baris dengan ratarata tersebut.

3. Membuat matriks kovarian $\mathbf{L}$,

$\mathbf{L}=\mathbf{X t} * \mathbf{X}$

4. Mencari nilai eigen (E) dan vektor eigen (C) dari matriks kovarian $\mathbf{L}$. Mengurutkan nilai-nilai eigen dan vektor eigen dari yang terbesar sampai yang terkecil, lalu pilihlah vektor eigen yang berkorespondensi dengan nilai eigen yang sudah diurutkan tersebut (di sinilah tahap reduksi dimensi sebenarnya berada, dengan memilih vektor eigen tersebut, kita tidak perlu menggunakan seluruh dimensi data yang ada, dan biasanya berkurang cukup drastis).

5. Mencari komponen utama (principal component) $\mathbf{P}$, yaitu vektor eigen dari matriks $(\mathbf{X} * \mathbf{X} \mathbf{t})$ dengan menggunakan vektor eigen dari matriks $(\mathbf{X t} * \mathbf{X})$, $\mathbf{P}=\mathbf{X} * \mathbf{C}$

6. Menghitung komponen utama citra-citra latihY,

$\mathbf{Y}=\mathbf{P t} * \mathbf{X}$

Hasil transformasi ini merupakan gambar wajah yang telah direduksi menjadi beberapa variable yang diperlukan saja yang akan dimasukkan ke jaringan syaraf tiruan.[4]

\subsection{Jaringan Syaraf Tiruan}

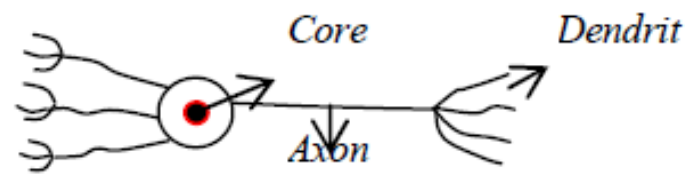

Gambar 3. Model Sel Syaraf Manusia
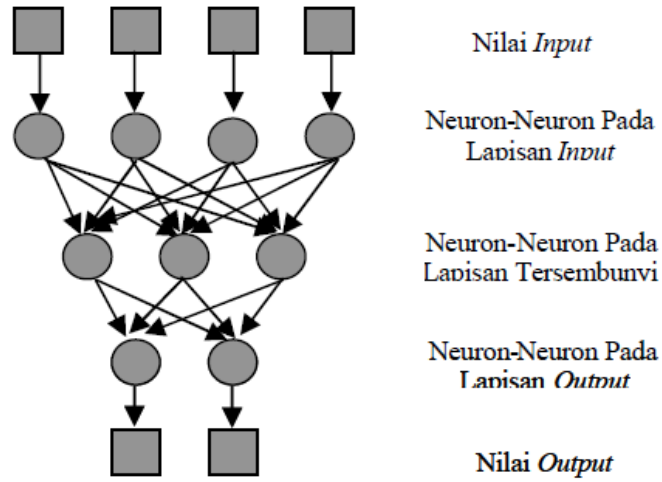

Gambar 4. Jaringan Syaraf Tiruan dengan 3 Lapisan.

\subsection{Perambatan-balik (Backpropagation)}

Proses pelatihan perambatan balik meliputi tiga tahap, yaitu: prosedur umpan maju, perhitungan serta perambatan balik kesalahan, dan penyesuainan bobot.

Algoritma perambatan balik diuraikan dalam langkah-langkah atau alur prosedur sebagai berikut.

1. Setiap unit masukan $\left(X_{n}, \mathrm{n}=1, \ldots, \mathrm{n}\right)$ menerima sinyal-sinyal masukan $\mathrm{X}_{\mathrm{n}}$ dan mengirimkan sinyal-sinyal ini ke unitunit selanjutnya (unit-unit tersembunyi).

2. Setiap unit tersembunyi $\left(I_{h}, \mathrm{~h}=1, \ldots, \mathrm{h}\right)$ menjumlahkan sinyal-sinyal terbobotnya:

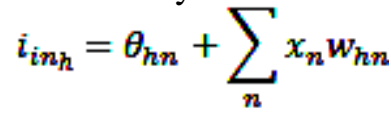

Kemudian menerapkan fungsi aktifasinya untuk menghitung sinyal keluarannya:

$I_{h}=f\left(i_{-} i_{h}\right)$

Lalu mengirimkannya pada semua unit lapis lapis keluaran.

3. Setiap unit keluaran $\left(O_{k}, \mathrm{k}=1, \ldots, \mathrm{k}\right)$ menjumlahkan sinyal masukan terbobotnya:

$$
o_{i n_{k}}=\theta_{k h}+\sum_{h} i_{h} w_{k h}
$$

Kemudian menerapkan fungsi aktifasi untuk menghitung sinyal keluarannya:

$\boldsymbol{o}_{k}=\boldsymbol{f}\left(\boldsymbol{o}_{-} i \mathrm{n}_{k}\right)$

Perhitungan dan perambatan balik kesalahan

4. Pada setiap unit keluaran $\left(O_{k}, \mathrm{k}=1, \ldots\right.$, k) menerima sebuah pola keluaran target yang berhubungan dengan pola masukan pelatihan, untuk menghitung informasi kesalahannya,

$$
\delta_{k}=\left(t_{k}-o_{k}\right) f^{\prime}\left(o_{k}\right)
$$

Lalu dihitung besar koreksi bobotnya (untuk memperbaiki $w_{k h}$ ).

$$
\Delta w_{k h}=a \delta_{k} I_{h}
$$

Selanjutnya dihitung besar koreksi biasnya (yang akan digunakan untuk memperbaiki $\left.\theta_{k h}\right)$.

$\Delta \theta_{k h}=a \delta_{k}$

dan mengirimkan $\delta_{k}$ ke unit-unit lapis tersembunyi. 
5. Pada setiap unit tersembunyi $\left(I_{h}, \mathrm{~h}=1\right.$, ..., h) masukan deltanya (dari unit-unit lapis keluaran) dijumlahkan.

$\delta_{-} i n_{h}=\sum_{k} \delta_{k} w_{k h}$

Kemudian hasil ini akan digunakan untuk menghitung besar informasi kesalahannya,

$$
\delta_{h}=\delta_{-} i n_{h} f^{\prime}\left(i_{h}\right)
$$

Lalu dihitung besar koreksi bobotnya (untuk memperbaiki $w_{h n}$ ),

$\Delta w_{h n}=\alpha \delta_{h} x_{n}$

Dan dihitung koreksi biasnya (untuk memperbaiki $\theta_{h n}$ ),

$$
\Delta \theta_{h \boldsymbol{n}}=\alpha \delta_{\boldsymbol{h}}
$$

Perbaikan bobot dan bias

6. Masing-masing unit keluaran $O_{k},(\mathrm{k}=1$, $\ldots, \mathrm{k})$ diperbaiki bobot dan biasnya.

$$
\begin{aligned}
& w_{k h}(\text { baru })=w_{k h}(\text { lama })+\Delta w_{k h} \\
& \theta_{k h}(\text { baru })=\theta_{k h}(\text { lama })+\Delta \theta_{k h}
\end{aligned}
$$

7. Masing-masing unit tersembunyi $\left(I_{h}, \mathrm{~h}\right.$ $=1, \ldots, \mathrm{h}$ ) diperbaiki bobot dan biasnya.

$$
\begin{aligned}
& w_{h n}(\text { baru })=w_{h n}(\text { lama })+\Delta w_{h n} \\
& \theta_{h n}(\text { baru })=\theta_{h n}(\text { lama })+\Delta \theta_{h n}
\end{aligned}
$$

8. Proses berhenti pada saat koreksi kesalahan mencapai minimum.

Konvergen akan lebih cepat dicapai bila menggunakan penambahan metode momentum untuk perbaikan bobot. Perumusan bobot unit keluaran perambatan balik dengan momentum terlihat dalam persamaan berikut.

$w_{k h}(t+1)=w_{k h}(t)+\alpha \delta_{k} i_{h}+\mu\left[w_{k h}(t)-w_{k h}(t-1)\right]$ atau,

$$
\Delta w_{k h}(t+1)=\alpha \delta_{k} i_{h}+\mu \Delta w_{k h}(t)
$$

perbaikan pada unit tersembunyi:

$w_{h n}(t+1)=w_{h n}(t)+\alpha \delta_{h} x_{n}+\mu\left[w_{h n}(t)-w_{h n}(t-1)\right]$ atau,

$$
\Delta w_{h n}(t+1)=a \delta_{h} x_{n}+\mu \Delta w_{h n}(t)
$$

Setelah pelatihan, sebuah JST perambatan-balik hanya menggunakan tahap umpan-maju untuk prosedur pengenalan. Hasil perhitungan aktivasi $Y_{k}$ dari proses umpan-maju pengenalan merupakan keluaran akhir jaringan. Untuk inisialisasi bobot awalnya digunakan bobot-bobot hasil pelatihan. [5]

\section{ANALISIS DAN PERANCANGAN SISTEM \\ 3.1 Perancangan Sistem dan Perangkat Lunak \\ a. Proses PCA}
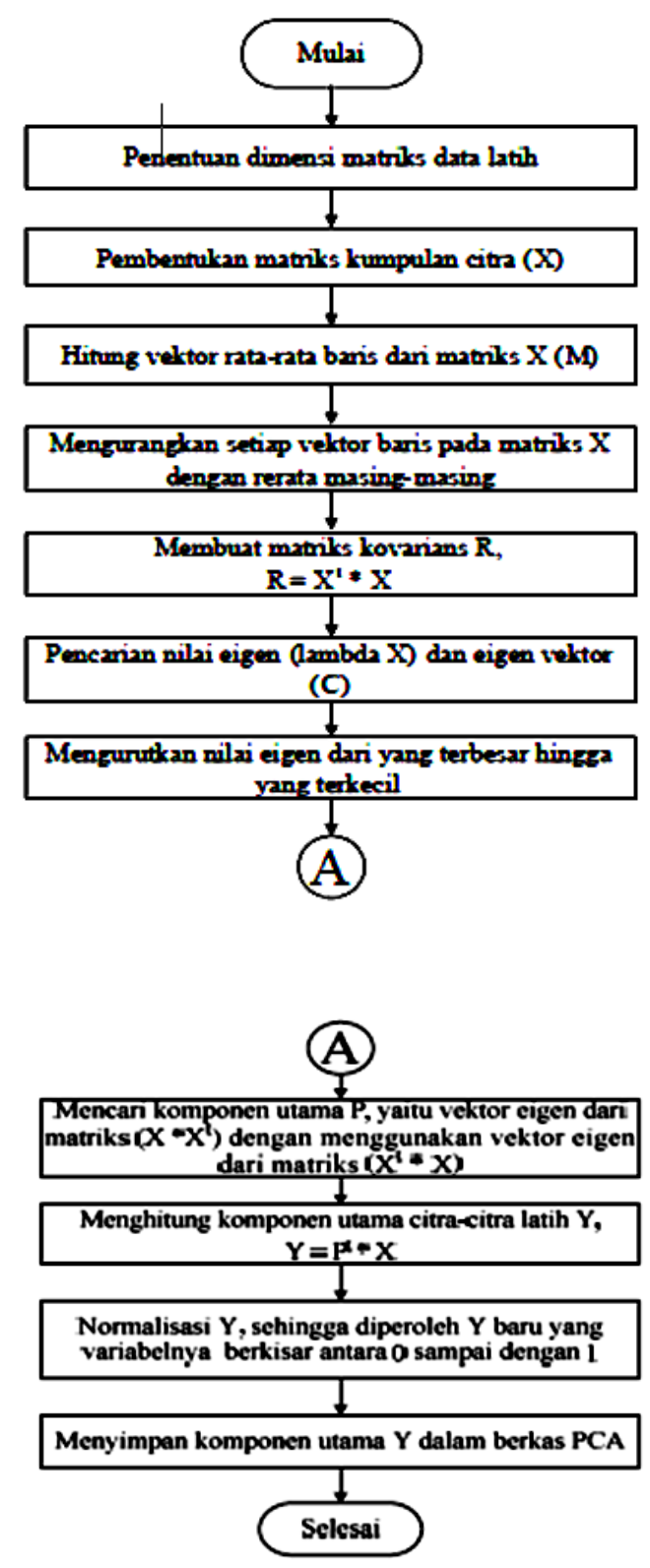

Gambar 5. Diagram Alur Proses PCA 
b. Proses JST

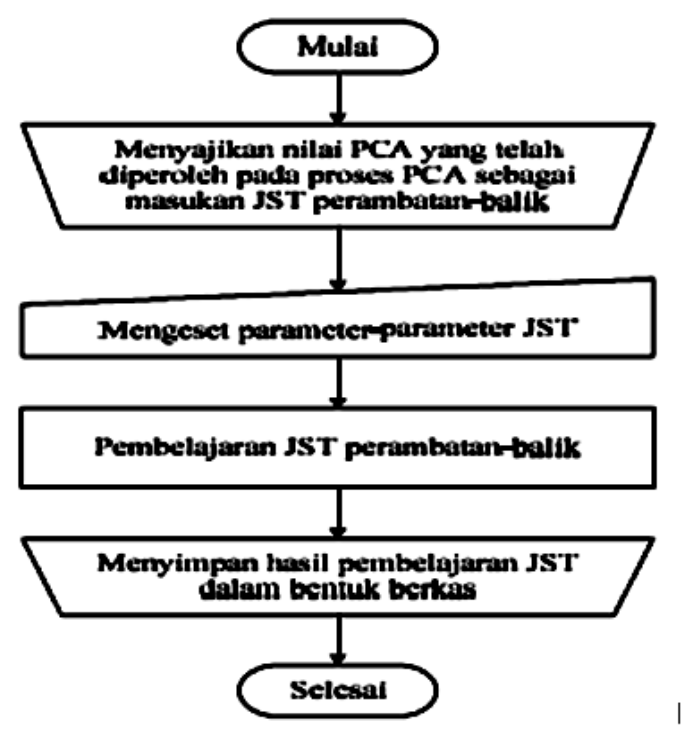

Gambar 6. Diagram Alur Proses JST

c. Proses Pengenalan Wajah

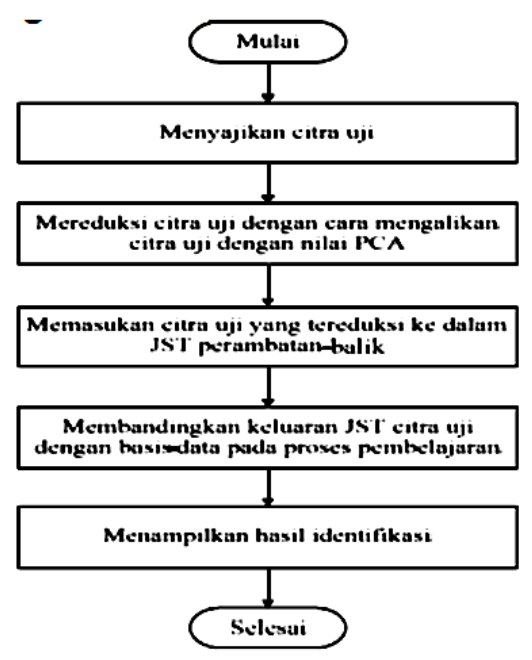

Gambar 7. Diagram Alur Proses Pengenalan Wajah

\subsection{Perancangan Sistem dan Perangkat Lunak}

a. Langkah-langkah Pengujian

Selanjutnya penulis akan membahas hasil penelitian Pengenalan Wajah Manusia Menggunakan Analisis Komponen Utama (PCA) dan Jaringan Syaraf Tiruan Perambatan Balik, yang dibagi dalam beberapa jenis penelitian, yaitu:

1. Pengaruh jumlah citra latih terhadap hasil pengenalan wajah;

2. Pengaruh jumlah komponen utama yang digunakan untuk pelatihan terhadap hasil pengenalan;
3. Pengaruh parameter JST pada pelatihan;

4. Pengujian menggunakan data hasil pengambilan menggunakan kamera digital;

5. Pengujian menggunakan citra uji luar berupa wajah dan citra uji luar bukan wajah (citra hewan). [6]

\section{b. Citra dalam Pengujian}

Citra wajah yang digunakan dalam pengujian sistem merupakan citra hasil unduh dari internet. Citra tersebut terdiri dari kumpulan citra wajah dari Olivetti Research Laboratory (ORL) di Cambridge, Inggris yang diambil antara April 1992 dan April 1994 dan citra bukan wajah (citra hewan). Dari 40 orang diambil 15 orang secara acak. Kemudian diambil 4 citra dari masing-masing orang untuk dimasukkan ke dalam berkas data latih, dan 4 citra lainya dimasukkan ke dalam berkas data uji. Sehingga jumlah keseluruhan data latih dan data uji masingmasing adalah 60 citra. Selain citra wajah hasil unduh dari internet, adapula citra wajah yang diambil sendiri dengan menggunakan kamera digital (Olympus) 8 mega piksel. Seluruh citra tersebut berukuran 46 x 56 piksel, dengan tipe aras keabuan.

c. Pengujian Pengaruh Jumlah Citra Latih Pada pengujian ini menggunakan data hasil unduh dari internet, dan parameterparameter JST menggunakan pengaturan default yaitu:

$\begin{array}{ll}\text { Hiden Layer ke-1 } & =8 \\ \text { Jumlah Iterasi } & =3000 \\ \text { Target Error } & =0,0001 \\ \text { Learning Rate } & =0,75 \\ \text { Momentum } & =0,25\end{array}$
berikut:

Hasil pengujian diuraikan sebagai

1. Pengujian menggunakan 1 citra latih menghasilkan 45 kesalahan pengenalan dari 60 pengujian.

2. Pengujian menggunakan 2 citra latih menghasilkan 38 kesalahan pengenalan dari 60 pengujian.

3. Pengujian menggunakan 3 citra latih menghasilkan 33 kesalahan pengenalan dari 60 pengujian.

4. Pengujian menggunakan 4 citra latih menghasilkan 9 kesalahan pengenalan dari 60 pengujian. 


\section{d. Pengujian Pengaruh Jumlah Komponen Utama}

Pengujian pengaruh jumlah komponen utama terhadap hasil pengenalan ini menghasilkan data-data sebagai berikut.

1. Pengujian menggunakan 60 komponen utama menghasilkan 9 kesalahan pengenalan dari 60 pengujian.

2. Pengujian menggunakan 8 komponen utama menghasilkan 9 kesalahan pengenalan dari 60 pengujian.

3. Pengujian menggunakan 7 komponen utama menghasilkan 9 kesalahan pengenalan dari 60 pengujian.

4. Pengujian menggunakan 6 komponen utama menghasilkan 12 kesalahan pengenalan dari 60 pengujian

\section{e. Pengujian Pengaruh Parameter JST Pada Pelatihan}

Proses pengujian pada pelatihan ini dilakukan dengan mencari konfigurasi terbaik dengan cara mengubah learning rate, momentum, dan jumlah neuron secara cobacoba (trial and error). Penentuan jumlah neuron, learning rate, momentum, target error, dan jumlah iterasi adalah hal terpenting dalam menentukan arsitektur dan parameter terbaik bagi jaringan syaraf tiruan pada proses pelatihan sehingga diharapkan proses pelatihan berlangsung dengan cepat dan kovergen untuk mencapai target error tertentu.

Setelah melakukan percobaan dengan cara mengubah-ubah parameter JST yang telah disebutkan diatas secara coba-coba, diperoleh hasil terbaik pengenalan dengan parameter JST sebagai berikut:

$\begin{array}{ll}\text { Hiden Layer ke-1 } & =8 \\ \text { Jumlah Iterasi } & =3000 \\ \text { Target Error } & =0,001 \\ \text { Learning Rate } & =0,75 \\ \text { Momentum } & =0,25\end{array}$

Pada pengujian ini menggunakan 10 komponen utama dari 4 buah citra latih. Hasil pengujian diperoleh 6 kesalahan pengenalan dari 60 pengujian, dengan persentase tingkat keberhasilan pengenalan adalah 90\%.[7] f. Pengujian Menggunakan Data Hasil Pengambilan Menggunakan Kamera Digital

Pada pengujian ini baik PCA maupun JST menggunakan setingan terbaik yang diperoleh pada pengujian-pengujian sebelumnya, dengan harapan setingan terbaik tersebut juga merupakan setingan terbaik pada pengujian ini.

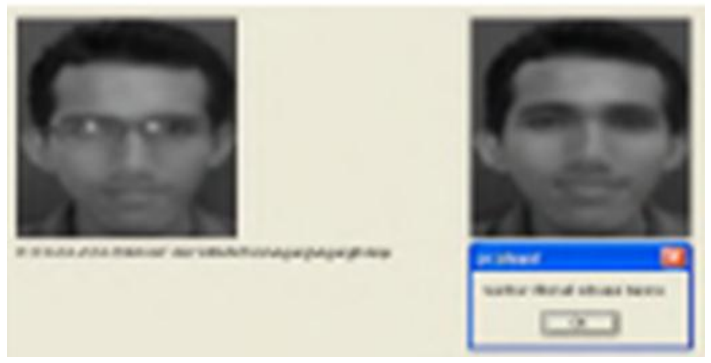

Gambar 8. Contoh Citra Wajah Pada Pengujian

Jumlah kesalahan pengenalan pada pengujian ini adalah 2 buah dari 60 pengujian, dengan persentase tingkat keberhasilan pengenalan adalah $96,67 \%$.

g. Pengujian Menggunakan Citra Uji Luar Berupa Wajah dan Citra Uji Luar Bukan Wajah (Citra Hewan)

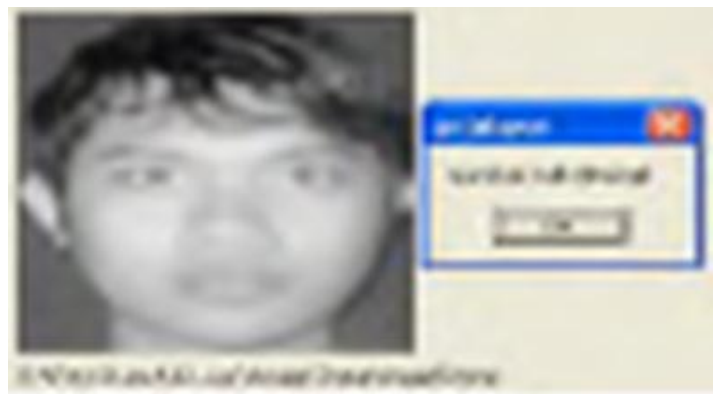

(a)

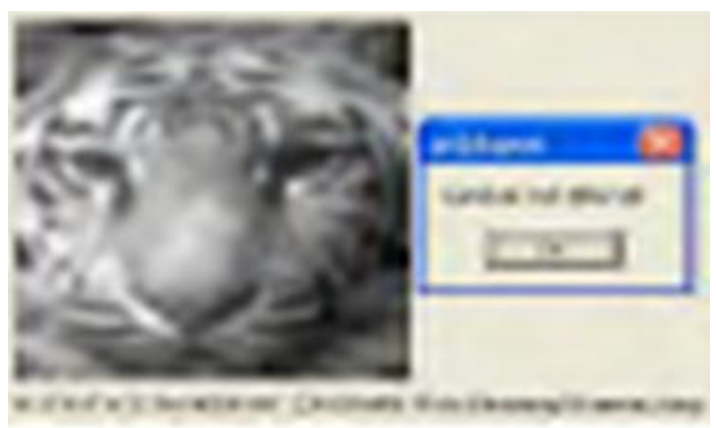

(b)

Gambar 9. Contoh Citra Wajah (a) dan Citra Hewan (b) pada Pengujian 
Jumlah kesalahan pengenalan pada pengujian ini adalah 1 buah dari 60 pengujian, dengan persentase tingkat keberhasilan pengenalan adalah $98,33 \%$. Satu kesalahan pengenalan tersebut terjadi pada pengujian menggunakan citra uji luar berupa wajah, sedangkan pengujian menggunakan citra uji luar bukan wajah tidak menghasilkan kesalahan pengenalan. [8]

\section{KESIMPULAN}

Berdasarkan proses yang telah dilakukan pada tugas akhir ini, mulai dari perancangan sampai pengujian dan analisis sistem, dapat disimpulkan beberapa hal, antara lain:

1. Penggabungan dua metode yaitu analisis komponen utama (PCA) dan jaringan syaraf tiruan perambatan-balik yang diterapkan dalam system pengenalan wajah memberikan hasil yang sangat baik. Hal ini ditunjukkan dengan tingkat pengenalan selama pengujian, yaitu dengan tingkat pengenalan rata-rata $85 \%$;

2. Jumlah citra latih yang digunakan pada penelitian ini berbanding lurus dengan kinerja system pengenalan wajah, artinya semakin banyak citra latih yang digunakan untuk pelatihan, hasil pengenalannya akan semakin baik;

3. Vektor ciri keluaran dari PCA dapat dikurangi jumlah komponen utamanya sampai pada jumlah tertentu (dalam penelitian ini sampai dengan 7 komponen utama masih bisa memberikan hasil pengenalan yang sama baiknya dengan menggunakan semua komponen utama, yaitu 60 komponen utama). Hasil ini lebih baik jika dibandingkan dengan penelitian dari Wibowo, yang mana pengurangan komponen utamanya hanya sampai 30 komponen utama;

4. Tingkat keberhasilan sistem terbaik menggunakan data dari Olivetti Research Laboratory (ORL) adalah mencapai $90 \%$; tingkat keberhasilan system terbaik menggunakan data hasil pengambilan menggunakan kamera digital (Olympus) 8 mega piksel adalah 96,67 $\%$. Sedangkan pada penelitian Wibowo pengambilan data menggunakan media kamera digital yang terpasang pada telepon genggam Nokia seri 6600 dan hasil unduh dari internet, dan tingkat keberhasilan pe-ngenalannya selama pelatihan yaitu $95 \%$.

5. Hasil pengujian menggunakan data hasil pengambilan dengan kamera digital menunjukkan hasil lebih baik jika dibandingkan dengan penelitian Wibowo, sebab citra-citra diambil dengan tidak memperhatikan tingkat pencahayaan (siang ataupun malam hari), tempat pengambilan dan bayangan wajah yang timbul akibat efek pencahayaan yang kurang baik. Selain itu tingkat variasi citra yang lebih banyak (ekspresi, posisi, dan aksesoris wajah), sedangkan pada penelitian Wibowo citra wajah yang digunakan adalah citra wajah lurus tampak depan dan mendapat tingkat pencahayaan yang sama.

6. Pelatihan untuk mendapatkan tingkat akurasi dalam pengenalan dengan jaringan syaraf tiruan perambatan-balik yang terbaik adalah sebagai berikut.
a. Hiden layer ke-1
$=8$
b. Jumlah iterasi
$=3000$
c. Target galat
$=0,001$
d. Laju pembelajaran
$=0,75$
e. Momentum
$=0,25$

7. Secara umum penggabungan dua metode yaitu analisis komponen utama (PCA) dan jaringan syaraf tiruan perambatan-balik yang diterapkan dalam sistem pengenalan wajah lebih baik jika dibandingkan dengan hanya memakai metode analisis komponen utama (PCA) saja.

\section{DAFTAR PUSTAKA}

[1] Arymurthy, A. Murni. dan S. Se-tiawan, Pengantar Pengolahan Citra, Elex Media Komputindo, Jakarta, 1992.

[2] Gunadi, K. dan Sonny R.P., Pembuatan Perangkat Lunak Penge-nalan Wajah Menggunakan Principal Component Analysis. Fakultas Teknologi Industri, Jurusan Teknik Informatika, Universitas Kristen Petra. 
[3] Wibowo, B.B., Pengenalan Wajah Menggunakan Analisis Komponen Utama (Principal Components Analysis), Tugas Akhir Mahasiswa S-1 Teknik Elektro Universitas Diponegoro, Semarang, 2005.

[4] Gunadi, K. dan Sonny R.P., Pembuatan Perangkat Lunak Penge-nalan Wajah Menggunakan Principal Component Analysis. Fakultas Teknologi Industri, Jurusan Teknik Informatika, Universitas Kristen Petra.

[5] Herlambang, Y., Aplikasi Jaringan Saraf Tiruan Pada Deteksi Wajah, Tugas Akhir Mahasiswa S-1 Teknik Elektro Universitas Diponegoro, Semarang, 2004.
[6] Kristanto, A., Jaringan Syaraf Tiruan (Konsep Dasar,Algoritma, dan Aplikasi), Gava Media, Yogyakarta, 2004.

[7] Siang, J.J., Jaringan Syaraf Tiruan dan Pemogramannya menggunakan Matlab, ANDI, Yogyakarta, 2005.

[8] K. Etemad and R. Chellappa, "Discriminant Analysis for Recognition of Human Face Images," Journal of Optical Society of America A, pp. 1724-1733, Aug. 1997.

[9] PCA Based Face Recognition System, http://www.mathworks.com/matlabcentr al/file exchange/17032, Desember 2012. 